\title{
Meu projeto literário
}

\author{
Luiz Ruffato
}


Depois da experiência do romance-mosaico Eles eram muitos cavalos, que tem como personagem principal a cidade de São Paulo, comecei a elaborar o Inferno provisório, que recupera e amplia a proposta formal anterior, desta vez perseguindo uma reflexão sobre a formação e a evolução do proletariado brasileiro a partir da década de 1950, quando tem início a profunda mudança do nosso perfil socioeconômico. Em cinquenta anos, passamos de uma sociedade agrária para uma sociedade pós-industrial - história que bem poderia ser sintetizada nos versos do compositor Caetano Veloso: "aqui tudo parece que é ainda construção e já é ruína". Projetado idealmente para cinco volumes, Inferno provisório tenta subsidiar a seguinte inquietação: como chegamos onde estamos?

Evidentemente, essa descrição abarca apenas a superfície da narrativa. Contudo, é o entrecruzamento das experiências "de fora" e "de dentro" dos personagens o que me interessa. Importa-me estudar o impacto das mudanças objetivas (a troca do espaço amplo pela exiguidade, a economia de subsistência pelo salário etc.) na subjetividade dos personagens. Erigir essa interpenetração da História com as histórias, acompanhar a transformação do país pelos olhos de quem verdadeiramente a comanda, eis minha proposta.

Para concretizá-la, assumo o risco de problematizar também o conceito de romance - como acompanhar a vertigem transformadora dos últimos cinquenta anos sem colocar em xeque a própria estrutura da narrativa? Assim, cada volume é composto de várias "histórias", unidades compreensíveis se lidas separadamente, mas funcionalmente interligadas, pois que se desdobram e se explicam e se espraiam umas nas outras. Personagens secundárias, aqui, tornam-se protagonistas ali; personagens apenas vislumbradas, ali, mais à frente se concretizam. E a linguagem acompanha essa turbulência - não a composição, mas a decomposição.

Luiz Ruffato é autor de Eles eram muitos cavalos (Boitempo, 2001); e do projeto literário Inferno provisório planejado para cinco volumes, dos quais quatro estão publicados: Mamma, son tanto felice (Record, 2005), O mundo inimigo (Record, 2005), Vista parcial da noite (Record, 2006) e O livro das impossibilidades (Record, 2008). 